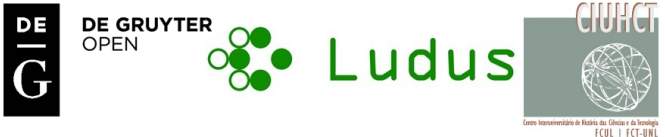 Games and Puzzles
}

\section{"A DifFicUlT CASE": PACIOLI AND Cardano on the Chinese Rings}

\author{
Albrecht Heeffer, Andreas M. Hinz \\ Center for History of Science, Ghent University, Mathematics Department, LMU Munich \\ albrecht.heeffer@ugent.be hinz@math.lmu.de
}

\begin{abstract}
The Chinese rings puzzle is one of those recreational mathematical problems known for several centuries in the West as well as in Asia. Its origin is difficult to ascertain but is most likely not Chinese. In this paper we provide an English translation, based on a mathematical analysis of the puzzle, of two sixteenth-century witness accounts. The first is by Luca Pacioli and was previously unpublished. The second is by Girolamo Cardano for which we provide an interpretation considerably different from existing translations. Finally, both treatments of the puzzle are compared, pointing out the presence of an implicit idea of non-numerical recursive algorithms.
\end{abstract}

Keywords: Chinese rings, recreational problems, Pacioli, Cardano.

\section{Introduction}

The Chinese rings feature as a well-known puzzle in many works on recreational mathematics. It is covered in all the classic works such as [22, 163-186], 3, 80-85], 8, Problem 417] and [12, 15-17]. In French nineteenth-century works (22], 13]), the puzzle is also known by the name 'Baguenaudier'. As the earliest source in Europe one often quotes Girolamo Cardano's De subtilitate [6, 294f], which gave it its alternative name 'Cardan's rings'. The aim of this paper is not to provide a complete overview on the history of the Chinese rings but to present for the first time an English translation of the earliest known European source, namely De viribus quantitatis by Pacioli [25, Capitolo CVII], which gives a reasonably detailed explanation of the puzzle as it was known at the beginning of the sixteenth century (Appendix 1). We will also discuss Cardano's treatment of the puzzle, which has become available recently in an English translation 
10. However, we are providing here an alternative translation based on a mathematical interpretation of Cardano's description (Appendix 2). While the puzzle has always fascinated mathematicians, such as Pacioli, Cardano and John Wallis in his De algebra tractatus [31, 472-478], it attracted the attention of modern mathematicians only since the booklet [13] became known through 22. The mathematical explanation that we present here is necessary for the interpretation of the texts by Pacioli and Cardano and our choice of material is focussed on this interpretation and the translations.

As for the Chinese sources, there remains a lot of confusion. References to rings, linked rings or interlocked rings date back to Sun Tzu's (544-496 BCE) The Art of War and the logic school of Hui Shih (380-305 BCE). However, the terse text fragments do not allow us to identify these as references to the puzzle as we know it. As an additional complication, there also exist a conjuring trick by the same name, with solid metal rings that appear to link and unlink and pass through each other, as well as wire puzzles with several pairs of interlocked irregular shaped rings that need to be separated. The tangram puzzle was also commonly referred to as the 'Chinese puzzle' during the nineteenth century. Joseph Needham briefly discusses the Chinese rings in his volume on mathematics [23, 111] and shows a drawing of a purchased specimen from the beginning of the nineteenth century (see Figure 1.

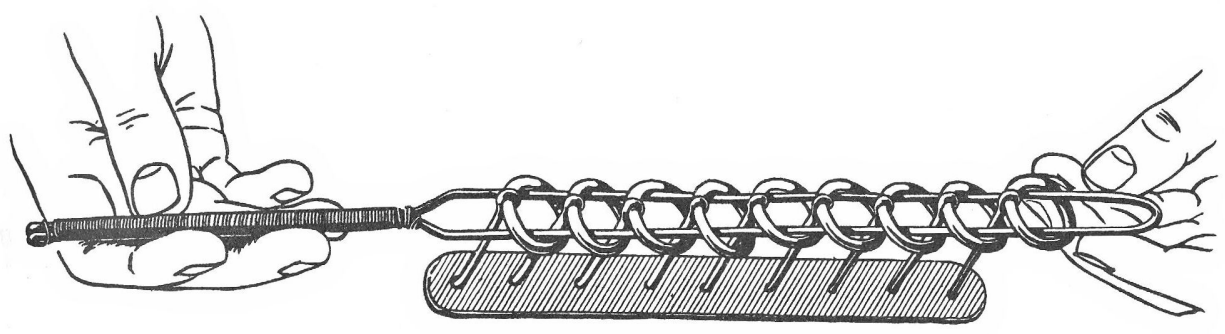

Figure 1: The puzzle as discussed by Joseph Needham.

Needham mentions that the puzzle is known by the name 'Ring of linked rings' but he remains cautious about its source, admitting that "its origin is quite obscure". The earliest depiction of the Chinese rings in a Chinese work appears to be in a painting by $\mathrm{Yu}$ Ji (1738-1823) of a lady holding a version of the puzzle with nine rings. Illustrations of the puzzle in books or material evidence are all of later dates. Curiously, the puzzle is treated in books on Japanese mathematics, or wasan, that precede these earliest Chinese sources, most prominently in the Shüki Sanpō by Yoriyuki Arima, 2] (see Figure 2]; cf. [7]. 


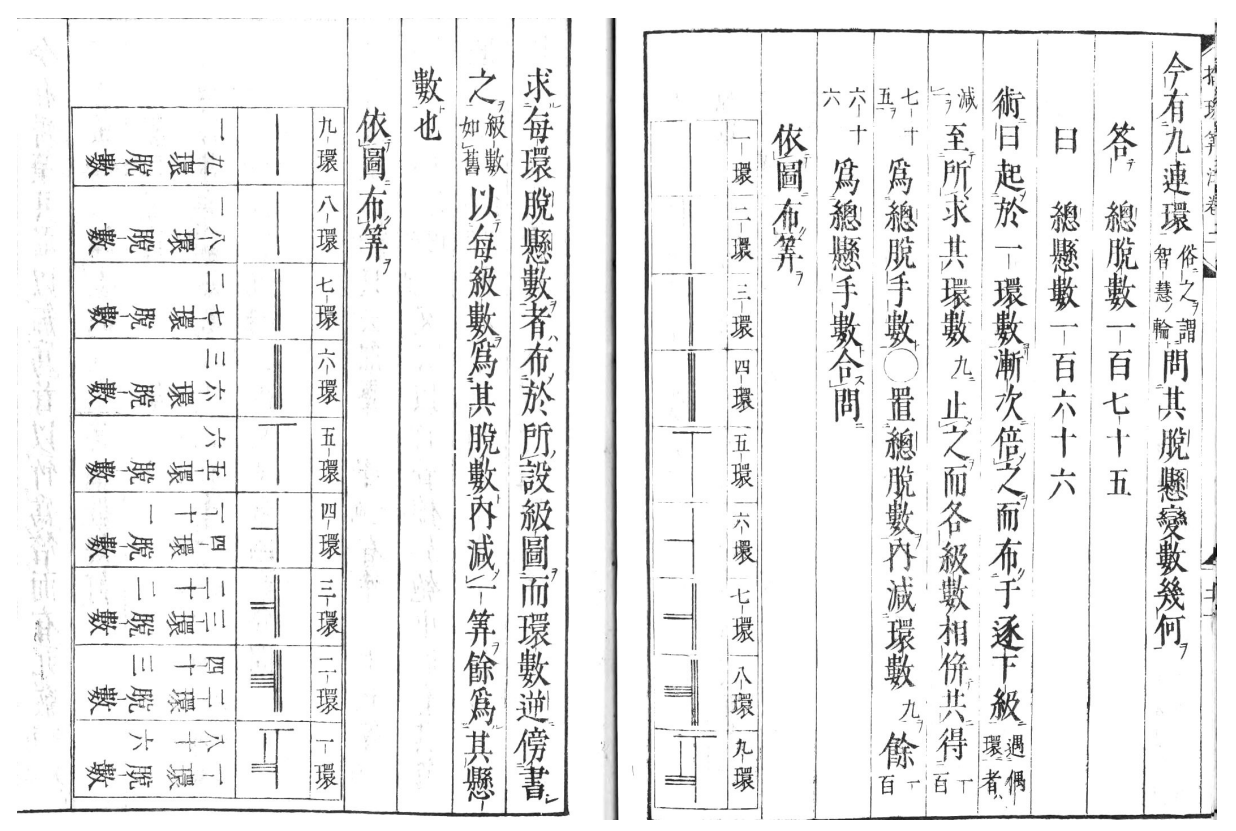

Figure 2: A solution to the puzzle from the Shūki Sanpō (National Diet Library Digital Collections).

\section{The name of the puzzle and its parts}

That this popular puzzle is termed in the West as 'Chinese rings' reveals the awareness of a cross-cultural influence. Remarkably however, none of our early sources mention a Chinese origin. The name may have come in use because of the popularity of exotic specimens of wonder from the Far East during the nineteenth century.

The rings, supported by individual rods, are arranged on a kind of loop as in Figure 1. In the chapter title, Pacioli uses the term 'strenghetta' for this loop. Queen Anna's New World of Words, a seventeenth-century Italian-English dictionary translates 'strengata' as 'a yark, or strip with a point'. The verb 'to yark' refers to the shoemaker's practice of sewing leather. In German, the most likely translation for 'strenghetta' would be 'Schlaufe', which translates into a heft or loop. Cardano refers to the puzzle as 'instrumentum ludicrum', or a playful tool. According to the Oxford English Dictionary, the puzzle was known as Tarriers or Tarrying irons in England at the beginning of the seventeenth century [28. In De algebra tractatus, Wallis spends six pages on De complicatis annulis or connected rings, and mentions Cardano as his main source. However, his version of the puzzle (see Figure 3 ) does not follow the description by Cardano but instead uses connected metal lamella, which suggests that he had such a specimen at his disposal. For the loop, Wallis does not adopt the term 'naviculum' from Cardano, but uses 'acum' (hair pin) or 'orbiculum' (revolving figure). Intriguingly, his analysis is based on nine rings, which is the more common version in Chinese sources. The configuration with nine rings is 
confirmed by the Chinese name for the puzzle which is jiulianhuan (nine linked rings 1

\section{P R O B L E M A.}

His ita paratis; Requiritur, 'Ut fic imponatur Acus, ut per omnes tranfeat An: nulos, omnes intra fe Clavos complectens: Atque ut (fic implicata) inde demum Expediatur.

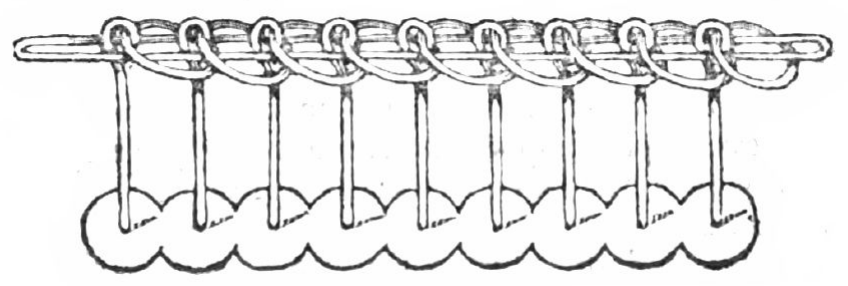

Figure 3: The puzzle as discussed by Wallis.

In a four-volume encyclopedic work on recreational problems by Jacques Ozanam, first published in two volumes as [24, the puzzle is shown as an illustration only (1725, IV, plate 16), (see Figure 4). However, Ozanam does not discuss it anywhere in the text. His version shows seven rings and the rods holding the rings are secured in a wooden or leather slat.

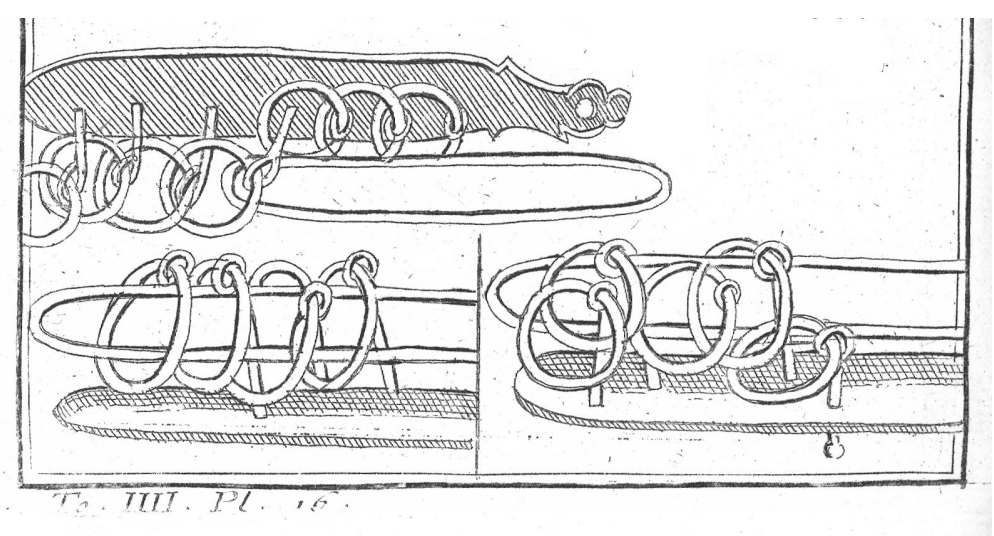

Figure 4: An illustration of the puzzle from [24].

None of the sources of the early nineteenth century mention a Chinese origin of the puzzle. Even Louis Gros, in his dedicated essay [13] on the baguenodier [sic!],

\footnotetext{
${ }^{1}$ However, the terms used in other languages do not refer to Chinese rings. In Korean, it is addressed as yu gaek ju (delay guest instrument). In German, it is called Zankeisen (quarrel iron) or Nürnberger Tand. Italians call it anelli di Cardano (Cardano's rings). In Russian the puzzle is known as meleda. In Swedish: Sinclairs bojor (Sinclair's shackles), and Finnish: Vangin lukko (Prisoner's lock) or Siperian lukko (Siberian lock).
} 
which contains an etymological introduction, does not mention the Chinese. Édouard Lucas, who discussed the puzzle first in the Revue Scientifique (2) 19(1880), 36-42, and later in his book 22, also uses the French term without mentioning a Chinese origin. However, in England in the 1860s, the term 'Chinese rings' starts to appear and grows more and more common. The earliest reference to the puzzle by this term we could find is a question proposed by G. S. Carr in Mathematical Questions and Solutions from The Educational Times, Vol. XVIII $(1873,31)$. The puzzle then appeared by this name in sales catalogues on games and pastimes as in the one by Peck and Snyder from New York (reprinted in [26]) or as a Japanese rings puzzle in Mr. Bland's Illustrated Catalogue of Extraordinary and Superior Conjuring Tricks (1889). Earlier English books describing the puzzle, such as The Magician's own book $(1857,280-283)$ do not refer to a Chinese origin. H. J. Purkiss calls it, in 1865, 'the common ring-puzzle' [27, 66]. So, it seems that the term 'Chinese rings' has been introduced only late in the nineteenth century.

\section{Origin and transmission}

The lack of any historical Chinese text describing the puzzle before Pacioli and Cardano, and the late adoption of the term 'Chinese rings' makes us circumspect about the possible Chinese origin of the puzzle. While it is difficult to determine a single origin of the contraption, it was probably invented only once. The rather complicated arrangement of rings, rods and bars makes it very unlikely that it was designed by several people independently or that it originated in different cultures simultaneously. Moreover, all extant versions are very similar, only differing in the number of rings, being mostly 7 or 9 . Also, whoever has invented the puzzle must have had an idea of how to solve it. The great majority of extant Chinese rings puzzles have an odd number of rings. This implies that, when starting with all rings on the bar, the best first move is by ring 1 , the one which is always free to be moved; for an even number of rings it would be ring 2 , the next in succession. There are several references to its use as a lock. Cardano describes it as a useless subtlety, "though it can be applied to the artful locks made for chests". The Finnish names refer to it as a lock and 22, 165] writes that it was used as a lock in Norway. The Japanese scholar of Dutch language and science, Genpaku Sugita 30, narrates how Gennai Hiraga managed to unlock a bag with the Chinese rings belonging to the Dutch chief Jan Crans at the Dutch trading company at Deshima, c. 1769 [28. As we do not know the inventor of the Chinese rings, his or her intention may have been to design an intricate lock, but we believe it served foremost a recreational purpose. 


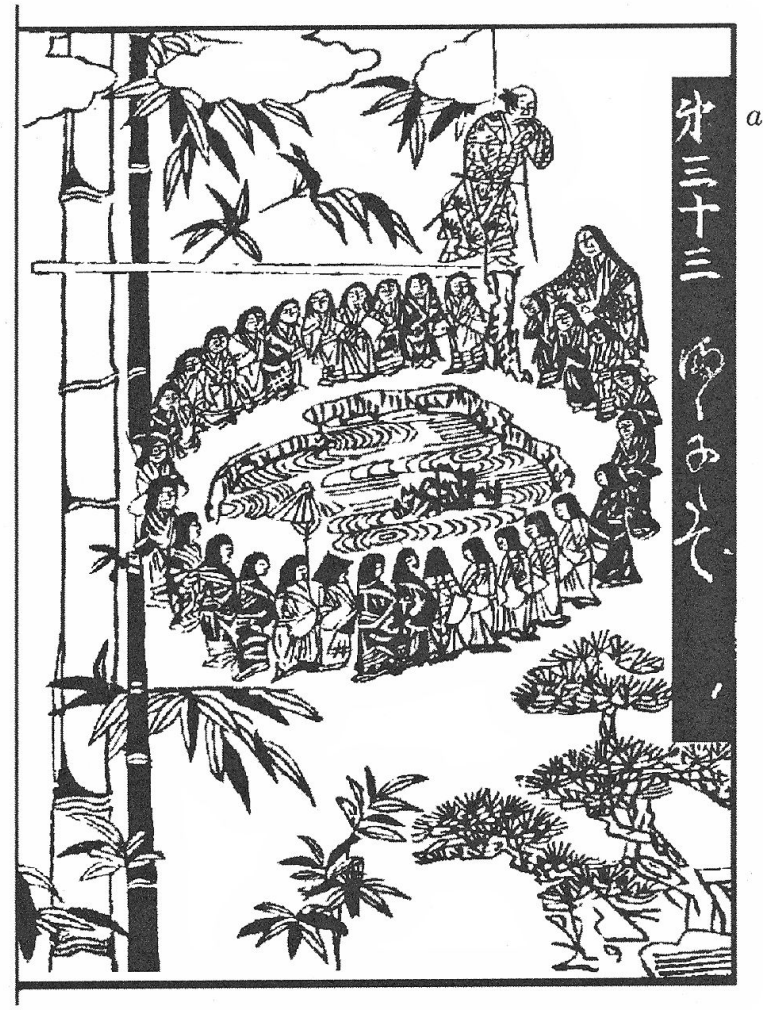

Figure 5: The mamakodate problem as it appears in the Jinkōki of 1627.

The Chinese rings puzzle is not the only recreational problem whose cultural origin is difficult to establish. While the use of the term 'Chinese rings' suggests a Chinese origin, the direction of influence might actually be from the West to the East. We may compare the question of its origin with the so-called Josephus problem, also treated by Pacioli in the De viribus quantitatis (problems 56-60) and by Cardano in his Practica Arithmetice (5], chap. 61, section 18, ff. $\left.\mathrm{T}^{\mathrm{iiii}} \mathrm{r}-\mathrm{T}^{\mathrm{v}} \mathrm{r}\right)$. The problem concerns counting out every $k$ th person standing in a circle of $n$ people, so that depending on the version of the problem, a given number of people remain or only the last person remains. The name 'Josephus problem' (Ludus Josephi) is given by Cardano who relates it to a passage in Josephus' De Bello Judaico (c. 80, Book III, chap. 8, sect. 7). The most common version in the Latin world is about 15 Christians and 15 Turks on a boat that is about to sink, unless 15 people are thrown overboard. If all 30 stand in a circle and every 9th person is thrown overboard the following sequence guarantees that only Turks are thrown overboard: $4,5,2,1,3,1,1,2$, 2, 3, 1, 2, 2, 1, meaning first 4 Christians, then 5 Turks, then 2 Christians, etc. These solutions are memorised by means of a vowel mnemonic. [29] was the first Western source to document that the Josephus problem was well known in Japan at least since the Jinkokki of 1627, one of the first books on wasan, traditional Japanese mathematics. The story here is of a wealthy farmer having thirty children, 15 from his first wife and 15 from the second, leaving his heritage to his single favorite son. Western, but also Japanese historians of mathematics 
have entertained the hypothesis that Jesuits residing in Japan from 1549 to the 1630s may have influenced the development of wasan ${ }^{2}$. Furthermore, there is the case of Hartsingus, a 'Japanese student' of mathematics at Leyden in 1654. However, none of these supposed influences can pass closer scrutiny [16]. A further complication is that the Japanese version of the problem, known as mamakodate, also features in literary works of a much older date. Though Josephus predates the earliest Japanese sources, it is nowhere evident to determine the direction of influence. It could have originated in Japan as well as in the Latin world.

Recreational problems such as the Josephus problem leave evidence of their existence as stories (Josephus), figures (as in Figure 5) or solidified solution recipes as the vowel mnemonics which allow us to trace the problem through historical sources. Such problems travel easily across cultural boundaries along the trade routes while embedding mathematical practices which become adapted to a new cultural context [15. With the Chinese rings puzzle, we also have the material culture of crafting, selling, transporting and using the contrivance. Material remains could shed some light on the origin of the puzzle, but extant examples are of recent dates. The puzzle shown by Needham (Figure 1) is a nineteenth-century copy. Unless a specimen would be excavated in a tomb dating before the sixteenth century, there is no solid evidence of its Chinese origin.

Pacioli's text is the earliest source of a mathematically inspired treatment of the Chinese rings puzzle. The De Viribus Quantitatis is an extensive compilation of puzzles, conjuring tricks and recreational problems. According to a dedicatory letter it was written from 1496 to 1508. However, in problem 129 there is a reference to a date in 1509, which indicates that the manuscript was still being edited during that year. The book was never published but survived as a manuscript owned by an eighteenth-century book collector, Giovanni Giacomo Amadei. It was later acquired by the University Library of Bologna [25. The dedication of the book and a request for a printing privilege was published by Boncompagni in his journal [4, 430-432]. These texts provide sufficient evidence for the attribution to Pacioli and the dating of the manuscript. A transcription of the text was published only in 1997 [1]. In 2009 a luxurious facsimile edition was published by the Aboca Museum with some commentaries [19].

\section{Mathematical interpretation}

The Chinese rings puzzle with $n \in \mathbb{N}_{0}$ rings can be modelled mathematically by a graph $R^{n}$ whose vertex set is $B^{n}, B:=\{0,1\}$, and where a pair $\{s, t\} \in\left(\begin{array}{c}B^{n} \\ 2\end{array}\right)$ belongs to the edge set, if the states represented by $s$ and $t$ differ by the move

\footnotetext{
2 29], 135: "could the mathematics of the West, or any intimation of what was being accomplished by its devotees, have reached Japan in Seki's time? These questions are more easily asked than answered, but it is by no means improbable that the answers will come in due time. We have only recently had the problem stated, and the search for the solution has little more than just begun."
} 
of one ring ${ }^{3}$. We write $s=s_{n} \ldots s_{1}$, where $s_{r}=0$, if $\operatorname{ring} r \in\{1, \ldots, n\}$ is off the loop and $s_{r}=1$, if it is on the loop; here ring 1 is the outermost ring and ring $n$ is the one closest to the handle. So $s$ is a word over the alphabet $B$ or a binary string (of length $n$ ). Figure 6 shows the example of graph $R^{3}$.

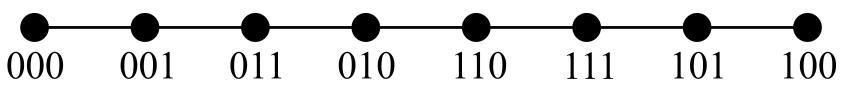

Figure 6: The graph $R^{3}$.

An easy theory shows that $R^{n}$ is isomorphic to $P_{2^{n}}$, the path graph on $2^{n}$ vertices, whence the shortest path between any two vertices is always unique. The pendant vertices of $R^{n}$ are $\alpha^{(n)}:=0^{n}=0 \ldots 0$ and $\omega^{(n)}:=10^{n-1}=10 \ldots 0$ (with $\left.\alpha^{(0)}=\emptyset=\omega^{(0)}\right)^{4}$. More on the mathematical theory of the Chinese rings can be found in [18, Chapter 1].

We will designate by $\ell_{n}$ (the length of) the path from $0^{n}$ to $1^{n}$ in $R^{n}$ and by $\bar{\ell}_{n}$ the $1^{n}, 0^{n}$-path (with the same length). The $\ell$ stands for Georg Christoph Lichtenberg (1742-1799), who in 1769 published the first (known so far) account of the lengths of these paths for general $n$; see [17. We then have

$$
\ell_{n}+\ell_{n-1}=M_{n},
$$

the Mersenne number $M_{n}=2^{n}-1$ being the length of the whole $0^{n}, 10^{n-1}$-path with $1^{n}=11^{n-1}$ lying on that path. Lichtenberg did not write out (1) explicitly, but instead derived the equivalent recurrence

$$
\ell_{0}=0, \ell_{n+1}=\ell_{n}+2 \ell_{n-1}+1 \text {. }
$$

\subsection{De viribus quantitatis}

Pacioli, who, of course, does not refer to a graph, describes the minimal solution for the task to get from $0^{7}$ to $1^{7}$, but does not account for the number of moves on that path. The first 8 moves, i.e. from 0000000 to 0001100 , are given explicitly in great detail. Then, for the first time, he alludes to a sequence of moves already done, namely $\bar{\ell}_{2}$, and tells us to do these moves in reverse, i.e. $\ell_{2}$, to arrive at 0001111 . The next instruction corresponds to an $\bar{\ell}_{3}$ leading to 0001000 and allowing ring 5 to go up: 0011000. Again, Pacioli evokes an $\ell_{3}$ which would result in 0011111, but he says "and you will have 6 on the loop". So he forgot or skipped voluntarily a 0011111,0111111-path, which amounts to $\bar{\ell}_{4}$ (4 rings down) plus 1 move upwards of ring 6 and then $\ell_{4}$ to reposition the first four rings on the loop. But then he resumes his strategy by saying that to move ring $7 \mathrm{up}$, "it is first necessary to pull down the first 5 ones", i.e. $\bar{\ell}_{5}$. To do this he can just run the procedure which led from 0000000 to 0011111 in reverse order, thereby switching $\ell$ and $\bar{\ell}$, because the presence of ring 6 on the loop does not change the mobility of the first 5 rings. Again he explains this explicitly,

\footnotetext{
${ }^{3}$ We have chosen a graph for a mathematical model of the Chinese rings specifically to connect with the explanations provided by Pacioli and Cardano. Readers unfamiliar with basics from graph theory are referred to, e.g., 32 .

${ }^{4}$ Inside a word, $l^{k}$ means a $k$-fold repetition of the letter $l$.

${ }^{5}$ By convention $\ell_{-1}=0$.
} 
i.e. $\bar{\ell}_{3}$, ring 5 down, $\ell_{3}, \bar{\ell}_{2}$, ring 4 down, $\ell_{2}, \bar{\ell}_{1}$, ring 3 down. At this point, at state 0100010 , a somewhat cryptic instruction follows, which can only mean $\ell_{1}$, ring 2 down, ring 1 down. since it must lead to 0100000 , when ring 7 can go up. Arriving at 1100000 , he spares the reader an $\ell_{5}$ to the final state 1111111 or either another $\bar{\ell}_{6}$ to arrive at 1000000 which would allow an 8th ring to move up and so on. This second interpretation is compatible with Pacioli's words "And in this way, successively you can place the others, one after the other".

Obviously, Pacioli had made the following observations:

1. Ring 1 is free, i.e. it can move at any time.

2. Ring $r+1$ can only be moved if ring $r$ is on the loop and all rings $<r$ are off: $0 \omega^{(r)} \leftrightarrow 1 \omega^{(r)}$. We may omit equal prefixes of any length, because rings $>r+1$ do not affect such a move.

3. After an up move of ring $r+1$, i.e. at $1 \omega^{(r)}$, one has to move up rings 1 to $r-1$ to arrive at $1^{1+r}$ and thereafter $r$ rings down to get to $\omega^{1+r}$. (This takes all in all $\ell_{r-1}+\bar{\ell}_{r}=\ell_{r-1}+\ell_{r}=M_{r}$ moves.)

4. Equivalently, starting in $01^{r}$, taking $r-1$ rings off leads to $0 \omega^{(r)}$, such that ring $r+1$ can be lifted up to $1 \omega^{(r)}$, and again lifting $r-1$ rings ends in $1^{1+r}$. (Here $\bar{\ell}_{r-1}+1+\ell_{r-1}=2 \ell_{r-1}+1=\ell_{r+1}-\ell_{r}$ moves have been performed; cf. (2).)

Pacioli, after the inevitable first lift of ring 1 according to observation 1 , follows point 4 for $r$ from 1 to 4 , then skips $r=5$ and resuming with $r=6$, he repeats details for the performance of $\bar{\ell}_{5}$ as the inverse of the $\ell_{5}$ that led him from 00000 to 11111 at the beginning. The final $\ell_{5}$, which would lead from 1100000 to 1111111 , or any further goal he then "spare[s] the reader".

The last sentence of Pacioli's Chapter 107 is very remarkable: if our interpretation, which is supported by the title of the chapter, is correct, he describes a two-player game in which one of the players starts in $1^{n}$, the other in $0^{n}$ and the winner is who first reaches the opposite state of the instrument, i.e. who can take off all $n$ rings from the loop, in other words pull the loop from the rings, or put them all up, i.e. place the loop into them, respectively. There is no other example in literature where such a competition based on the Chinese rings has been proposed!

\subsection{De subtilitate}

In Book XV, On uncertain-type or useless subtleties, Cardano first describes the material which is obviously the same as Pacioli is referring to; the number of rings is fixed to 7. Cardano uses the word navicula for what Pacioli named by the obscure word strenghetta. While we translated the latter with loop, we will employ shuttle, deriving from the weaver's tool, for Cardano's text.

This material, in addition to Pacioli's observations 1 and 2, allows for the first two rings to move simultaneously - up, if both are off, and down, if both are on the shuttle. This is what Lucas later called the marche accélérée (accelerated 
run) [22, 183f]. The graph $\widetilde{R}^{n}$ modelling this version, obviously for $n \geq 2$, is obtained from $R^{n}$ by adding edges between vertices ending in 00 and 11 and deleting all vertices (and their incident edges) ending in 01. It is again a path graph, but whose length is shortened to $3 \cdot 2^{n-2}-1$. In this setting, in contrast to all the other rings, ring 2 never walks alone, but always together with ring 1. The example of $\widetilde{R}^{3}$ is drawn in Figure 7

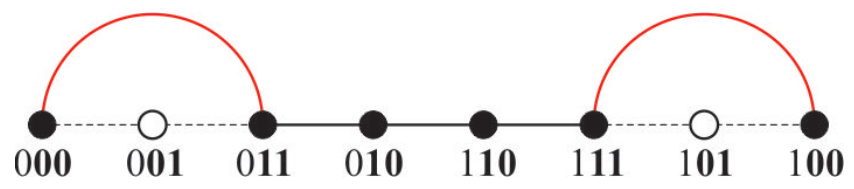

Figure 7: The graph $\widetilde{R}^{3}$.

Accordingly, Cardano starts, from state 0000000, by pulling up rings 1 and 2 to get 0000011 , from where he can drop down ring 1 to arrive at 0000010. So he used two "exchanges" instead of the three moves of individual rings. Now tbe third ring can be lifted to 0000110 and moving up ring 1 results in three rings on the shuttle 0000111. Then rings 1 and 2 can be dropped simultaneously to reach state 0000100 from which ring 4 can go up to 0001100.

Somewhat surprisingly, Cardano stops here with his stepwise description of the solution, because he believes that the procedure is already clear from that short introduction and that it follows three recipes:

1. "that the ring to be pulled up or dropped down should have only one in front of it enclosing the shuttle"

This is the same as Pacioli's observation 2. (Cardano mentions the first ring only later as the one which is free; cf. Pacioli's observation 1.)

2. "when you are dropping down, you should always let down the first two together after pulling up the first, or before dropping the first down you pull up the first two"

This is the statement that rings 1 and 2 should move simultaneously, if possible. The wording is not particularly clear, but it can only mean that the exchanges involving the first two rings always come in two, either two rings up, one down, i.e. $00 \rightarrow 11 \rightarrow 10$, or one ring up and two down, i.e. $10 \rightarrow 11 \rightarrow 00$.

3. "whichever is pulled up or dropped, all those in front must be pulled up, and again be dropped"

Again the wording is a bit ambiguous, but it probably refers to $00^{r} \rightarrow$ $01^{r} \rightarrow 010^{r-1} \rightarrow 110^{r-1} \rightarrow 11^{r} \rightarrow 10^{r}$ and $10^{r} \rightarrow 11^{r} \rightarrow 110^{r-1} \rightarrow$ $010^{r-1} \rightarrow 01^{r} \rightarrow 00^{r}$ for ring $r+1$ to move up or down, respectively, for $r \in\{2, \ldots, 6\}$. This can be compared with Pacioli's observation 4 . 
After stating his three instructions for the solution, Cardano emphasises the independence of the first two rings and claims, without proof, that state 111111 is reached (from 0000000) in 64 exchanges and that another 31 lead to 1000000. He then adds these numbers to arrive at 95 for the whole path $\widetilde{R}^{7}$ and even considers the way back with the same number of exchanges to summarize the round trip $\alpha^{(7)}\left(\rightarrow 1^{7}\right) \rightarrow \omega^{(7)}\left(\rightarrow 01^{6}\right) \rightarrow \alpha^{(7)}$, completed in 190 exchanges.

These four numbers are correct, i.e. they represent the values $p_{7}, p_{6}, 3 \cdot 2^{5}-1$ and $3 \cdot 2^{6}-2$, where $p_{n}=3 \ell_{n-2}+1$ is the length of the path from $0^{n}$ to $1^{n}$, named for Henri John Purkiss (cf. [17]), and the other two numbers stand for the length of the path $\widetilde{R}^{7}$ as seen before and its double. Note that, similarly as in (1), we have, for $n \geq 2$,

$$
p_{n}+p_{n-1}=3 \cdot 2^{n-2}-1 .
$$

\subsection{Comparison}

Given that the optimal, i.e. shortest, solution for the Chinese rings puzzle is unique, it comes as no surprise that the descriptions of Pacioli and Cardano are very similar. The main difference is that Cardano uses the accelerated rule to move ring 2 always together with ring 1 in one exchange. This could have led him, already after the first 6 exchanges, to the recipe of employing his instruction 2 alternately with a move of ring 3 in between and the only possible move of one ring different from 1,2 and 3 thereafter: $00 \rightarrow 10$, one move of ring $3,10 \rightarrow 00$, one move of some ring $r>3$. In that case, his instruction 3 is only needed to deduce the numbers of moves of rings $r \in\{4, \ldots, 7\}$, namely $2^{7-r}$, on the path from $\alpha^{(7)}$ to $\omega^{(7)}$. Then, after $6 \cdot \sum_{r=4}^{7} 2^{7-r}=6 \cdot 15=90$ exchanges we are in state 1000100 , so that after 5 more we arrive at the terminal state. Similarly, if we interrupt the sequence of moves of the larger 4 rings after the 10th already, i.e. after 60 exchanges, we are in state 1111000 and 4 more exchanges lead to $1^{7}$. This is a possible explanation for the four numbers occurring in Cardano's text.

Let us finally mention that none of the authors addressed the question of optimality of their solutions although minimality of the path length is usually assumed to be part of the problem in comparable puzzles like, e.g., the wolf, goat and cabbage problem. Note that describing a solution, as Pacioli and Cardano did, only gives an upper bound for the optimal length. Therefore, an additional argument is needed for the lower bound as, e.g., provided above by looking at the corresponding graph.

\section{Conclusion}

It is remarkable that the Chinese rings puzzle caught the attention of mathematicians such as Pacioli, Cardano, Wallis, Lichtenberg, and Arima long before a full theory was established by L. Gros. They all showed an interest in the mathematical aspects of the puzzle and all arrived at interesting results. They treat the Chinese rings not as a mere curiosity or pastime but recognize the combinatorial and recursive aspects of the mathematics behind the puzzle. 
Recursive thinking is present in both Pacioli's and Cardano's accounts. The former claims that once you know "the method", namely to get to 1100000, you can put up the other rings, the number of which he declares to be arbitrary from the beginning. The figure Pacioli refers to would obviously decide the question whether he is just describing a generalizable example, but the figure is unfortunately missing in the extant manuscript. Cardano restricts his treatment to seven rings (Wallis has nine) and definitely considers a finite path, namely from 0000000 to 1000000 and back again. But also here, some recursive thinking is present, because he stops his stepwise description already at 1100, which not coincidentally is the prototype of Pacioli's solution.

The first evidence for a general $n$ is due to Lichtenberg 20. 20 again has 9 rings, but something like recursion is mentioned (jiyaku-jutsu). Also he gives a general rule for how to get the next entry in his table(s) from the previous one. By the time of Gros and Lucas recurrence is, of course, well-established.

While Pacioli's description of the solution is more lucid, he does not deal with move numbers at all. Interestingly, both authors employ a certain form of non-numerical recursion in their solution procedure. As with mathematical induction, an implicit idea of recursive procedures seem to have been present at the beginning of the sixteenth century6. Although they both restrict themselves to $n=7$ rings, Pacioli admits that $n$ could be any number (larger than 2 ) and his as well as Cardano's algorithm could easily be extended to any number of rings $n \geq 2$.

Apart from the rather specific recursive character of the Arithmetical triangle, an often cited example of an early use of recursion is Fibonacci's rabbit problem [9, 404-5] leading to the first definition of an integer sequence by recurrence; cf. [21, p. 131]. However, it was not really noticed before the seventeenth century and we believe the case of Pacioli and Cardano here presented to be much closer to the modern concept of recursion than that of Fibonacci, or the inventors of the Arithmetical triangle for that matter, by applying it to a "method", thereby anticipating a non-numerical recursive algorithm.

\section{Acknowledgements}

The authors wish to thank Alexandra Wieser-Seibt (Krailling) and Giuseppe Primiero (London) for their help in translating the Italian texts. Albrecht Heeffer was supported by the Research Foundation Flanders (FWO Vlaanderen), project nr. 3G002713. Andreas M. Hinz was supported by the Slovenian Research Agency (ARRS) under the grant J1-7110.

\footnotetext{
${ }^{6}$ For a discussion on the use of mathematical induction in the abbaco period (before 1500), see [14.
} 


\section{References}

[1] Ahrens, Wilhelm. Mathematische Unterhaltungen und Spiele, Leipzig: B.G., Teubner, 1901.

[2] Arima, Yoriyuki. Shūki sanpō, [Edo]: Senshōdō, 1769.

[3] Ball, W. W. Rouse. Mathematical recreations and problems of past and present times, London: Macmillan and Co, 1892.

[4] Boncompagni, Baldessaro. "Appendice di documenti inediti relativi a Fra Luca Pacioli", Bullettino di bibliografia e di storia delle scienze matematiche e fisiche, 12 (June), 428-438, 1879.

[5] Cardano, Girolamo. Practica arithmetice 83 mensurandi singularis: in qua que preter alias continentur versa pagina demonstrabit, Mediolani: Io. Antonins Castellioneus Mediolani imprimebat, impensis B. Calusci, 1539.

[6] Cardano, Girolamo. Hieronymi Cardani Medici Mediolanensis De Subtilitate Libri XXI, Norimbergæ apud Ioh. Petreium (for a modern edition and translation, Forrester), 1550.

[7] Döll, Steffen; Hinz, Andreas M. "Kyū-renkan-the Arima sequence", Advanced Studies in Pure Mathematics, to appear.

[8] Dudeney, Henry Ernest. Amusements in Mathematics, London: Thomas Nelson, 1917.

[9] Fibonacci, Leonardo. Scritti di Leonardo Pisano, Baldassarre Boncompagni (ed.), Roma: Tipografia delle scienze matematiche e fisiche, 1857 (English translation by Laurence Sigler, Fibonacci's Liber Abaci: a Translation into Modern English of Leonardo Pisano's Book of Calculation, New York: Springer, 2002).

[10] Forrester, John (ed. tr.). The De subtilitate of Girolamo Cardano, Tempe, Arizona: Arizona Center for Medieval and Renaissance Studies, 2013.

[11] Garlaschi Peirani, Maria (ed.). De viribus quantitatis, Milano: Ente Raccolta Vinciana, 1997.

[12] Gardner, Martin. Knotted doughnuts and other mathematical entertainments, New York: W.H. Freeman, 1986.

[13] Gros, Louis. Théorie du Baguenodier par un clerc de notaire lyonnais, Lyon: Aimé Vingtrinier, 1872.

[14] Heeffer, Albrecht. "Regiomontanus and Chinese Mathematics", Philosophica, 83, 81-107, 2010.

[15] Heeffer, Albrecht. "How Algebra Spoiled Recreational Problems: a Case Study in the Cross-Cultural Dissemination of Mathematics", Historia Mathematica, 41(4), 400-437, 2014. 
[16] Heeffer, Albrecht. "Dutch Algebra and Arithmetic in Japan before the Meiji Restoration", in Ioannis M. Vandoulakis and Liu Dun (eds.) Navigating across Mathematical Cultures and Times. Exploring the Diversity of Discoveries and Proofs, World Scientific, Singapore, in print, 2018.

[17] Hinz, Andreas M. "The Lichtenberg Sequence", The Fibonacci Quarterly, $55(1), 2-12,2017$.

[18] Hinz, Andreas M.; Klavžar, Sandi; Milutinović, Uroš; Petr, Ciril. The Tower of Hanoi-Myths and Maths, Basel: Springer, 2013.

[19] Honsell, Furio; Bagni, Giorgio. De viribus quantitatis: Curiosita e divertimenti con i numeri., Sansepolcro: Aboca Museum, 2009.

[20] Lichtenberg, Georg Christoph. "Ueber das Spiel mit den künstlich verflochtenen Ringen, welches gewöhnlich Nürnberger Tand genannt wird", Göttingische Anzeigen von gemeinnützigen Sachen, 1, 637-640, 1769.

[21] Lucas, Édouard. "Recherches sur plusieurs ouvrages de Léonard de Pise et sur diverses questions d'arithmétique supérieure", Bulletino di Bibliografia e di Storia delle Scienze Matematiche e Fisiche, 10, 129-193, 239-293, 1877 .

[22] Lucas, Édouard. Récréations Mathématiques, Paris: Gauthier-Villars et fils, 1882 .

[23] Needham, Joseph; Ling Wang. Science and civilisation in China. Volume 3, Mathematics and the sciences of the heavens and the earth, Cambridge: Cambridge University Press, 1959.

[24] Ozanam, Jacques. Recreations mathematiques et physiques, qui contiennent plusieurs problêmes d'arithmetique, de geometrie, d'optique, de gnomonique, de cosmographie, de mecanique, de pyrotechnie, $\&$ de physique, Paris: J. Jombert, 1694.

[25] Pacioli, Luca. De viribus quantitatis, Codice n. 250 della Biblioteca Universitaria di Bologna, 1496-1509.

[26] Peck \& Snyder (company). Nineteenth century games \& sporting goods: sports equipment and clothing, novelties, recreative science, firemen's supplies, magic lanterns and slides, plays and joke books, tricks and magic, badges and ornaments, Princeton, N.J.: Pyne Press, 1971.

[27] Purkiss, Henry John. Question 1632 of the Mathematical Questions with their Solutions from the "Educational Times", Miller, W. J. (ed.), Vol. III, London: C. F. Hodgson \& Son, 66-67, 1865.

[28] Singmaster, David. Sources in Recreational Mathematics, An Annotated Bibliography, Eighth Preliminary Edition (unpublished, electronic copy from the author), 2004.

[29] Smith, David; Yoshio Mikami. A history of Japanese mathematics, Chicago: Open Court Pub. Co, 1914. 
[30] Sugita, Genpaku; Ogata, Tomio. Dawn of Western science in Japan, Rangaku kotohajime, [Tokyo]: Hokuseido Press, 1969.

[31] Wallis, Johannis. De Algebra Tractatus, Oxford: Theatrum Sheldonianum, 1693.

[32] West, Douglas. Introduction to Graph Theory, Upper Saddle River NJ: Prentice Hall, 2001.

\section{Appendix 1: Pacioli}

The transcription is made from [25, reproduced by Honsell and Bagni [19]. Ligatures and abbreviations have been expanded, the letters ' $u$ ' and ' $v$ ' have been differentiated and punctuation has been added, but otherwise the original spelling has been maintained, even where it is used inconsistently. The English translation closely follows the original text. For convenience to the reader, the states of the rings on the loop are shown with binary strings $s$ as explained in Section 4 put between square brackets: $[s]$.

Capitolo CVII: Do cavare et mettere una strenghetta salda in al quanti anelli saldi difficil caso

Molti hanno certa quantita de annelli saldi messi in certi gambi, quali asettano in una steccha piatta de legno o altro metallo, la quali gambi sonno commo chiuodi o vero aguti ognuno ficto nel suo foro alla fila in ditta stecha, in modo chel capo loro tenga, ch'non posino uscire, et la ponta de ognuno revoltata aluncino ch' tenga ognuna uno anello et ognuno delli anelli ha la ponta de laguto dentro.

Et poi, in ditta ponto fermato la nello el chiuodo non po ne avanze per lo capo ne adrieto per la nello ch' sta in la ponta revoltata dentro laltro anello. Et questi anelli possano essere piu de tre quanti te piaci. Ma manco non per chel giuoco non seria bello, et sonno situati uno in laltro commo vedi qui in [f. 212r] figura, salvo chel primo diloro non ha niuno dentro.

Da poi hanno una strengheta facta commo vedi, salda da ogni capo et in quella con bellissimo modo et in gegno in filzano tutti ditti anelli commenzando dal primo. Cioe da quello ch'é libero et metese in questo modo. Videlicet: Prima metti quello. $1^{\circ} \mathrm{p}^{\mathrm{o}}$ solo in traversandolo per taglio, ch' possa intrare, et gli altri tutti stanno a giacere insu ditta steccha.

Poi prendi el $2^{\circ}$ annello tirando lo su pel gambo del primo et tirandolo inanze al capo de detta strengheta. Lo mettera et arane' doi gia. Poi gettarai giu il primo insula steccha a giacere' et su pel gamdo del $2^{\circ}$ tirerai su el $3^{\circ}$, pingendolo inanze ch' nentri la stringhetta, comme prima festi per lo $2^{\circ}$, et messo ch' tu arai questo $3^{\circ}$, torneravi poi el primo ch' giu gettasti, quale dase e' libero, et tirato ch' larai su, et tu giu pel suo gambo getterai giu el secundo et ancho ditto primo in mo ch' in stangheta non resta se non el $3^{\circ}$.

Poi su pel gambo de questo tertio tirerai su el quarto con ducendolo in capo della strenghetta. Commo prima festi aglialtri. Poi tornarai superordine quelli doi primi ch' getasti gui et arane 4 in stanghetta. Poi ordinamente gettarai giu $\mathrm{p}^{\mathrm{o}} 2^{\mathrm{o}} 3^{\mathrm{o}}$ et solo el $4^{\circ}$ resti in stanghetta il quale a modo ditto tirera su el $5^{\circ}$. Poi pertira- [f. $212 \mathrm{v}$ ] re su el $6^{\circ}$ te bisogna retornare su tutti li 3 primi a modo ditto a uno auno et arane 6 in stanghetta et per tirare el $7^{\circ}$ bisogna ut prius gettar giu li primi 5. Cioe primo, secundo, tertio, quarto, quinto. 
El $5^{\circ}$ non sepi gettare se non quando sia gettati giu prima, $\mathrm{p}^{\circ}, 2^{\circ}, 3^{\circ}$, poi per lo gambo del quatro se getta giu el $5^{\circ}$. Poi se retorna, $\mathrm{p}^{\circ}, 2^{\circ}, 3^{\circ}$ per buttar giu el $\mathrm{q}^{\mathrm{o}}$, qual non se po gettare se non per lo gambo del $3^{\circ}$, per li quale medesimamente fo messo su, et pero se getta li primi doi. Cioe $\mathrm{p}^{\mathrm{o}}, 2^{\circ}$, et poi per lo gambo de ditto tertio se getta el quarto, poi se getta giu el tercio ma prima se tornano su li ditti doi, cioe primo, secundo e getta se giu el primo. Poi per lo gambo del $2^{\circ}$ se getta el $3^{\circ}$ commo sali su. E cosi urevitere li arai cavati tutti 5 é sira solo restato in stanghetta el $6^{\circ}$ anello per lo cui gambo farai andar su el $7^{\circ}$ e' cosi sucessive de mano in mano metterai li altri et parcas lector.

Per ch' non solo ascrivere el modo ma actu mostrandolo con fatiga el giovinelo a prende'. Ma son certo chel tuo ligiero in gegno alla mia diminuta scriptura suplire in quo plurimum confido ideo. Et di questi anche sene propone doi, uno ligato et laltro sciolto, achi prima asetta luno commo laltro venca.

\section{Chapter 107: Where a solid loop is pulled from and placed into any number of solid rings, a difficult case}

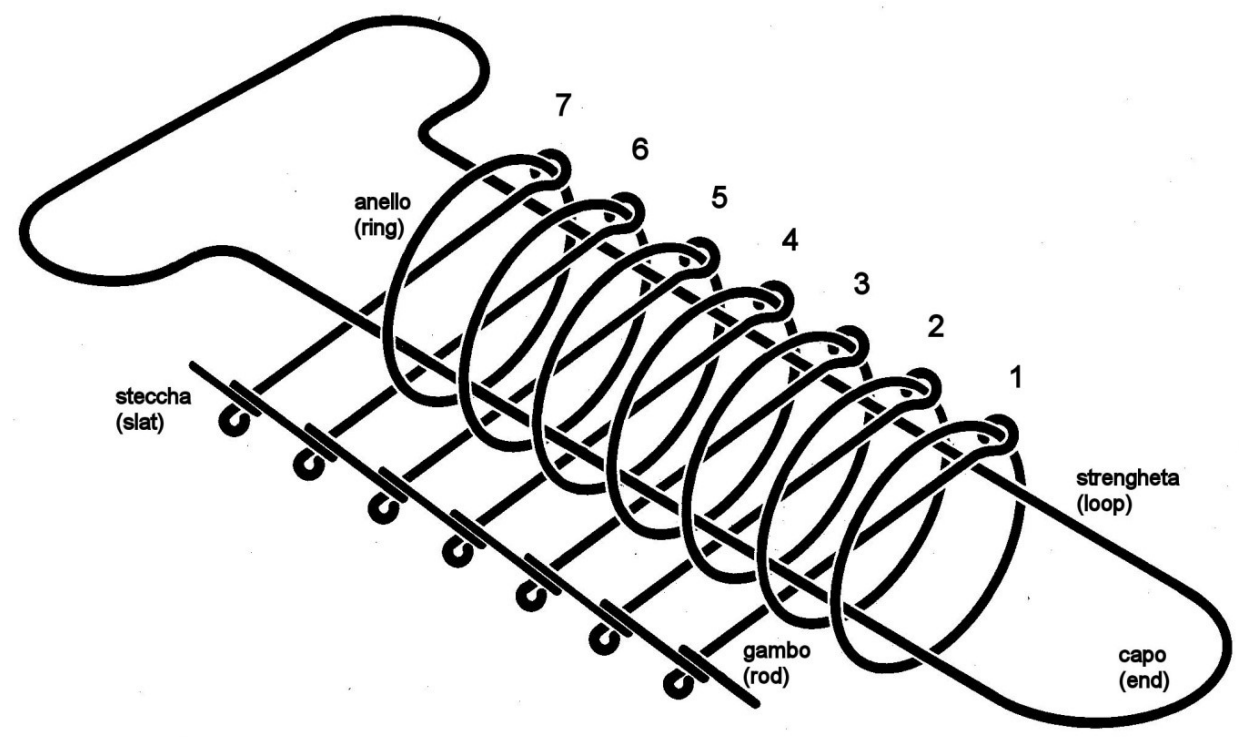

Figure 8: A reconstruction of the Chinese rings (state $1^{7}$ ) from Pacioli's description.

Many have a certain quantity of solid rings held by some rods which come together in a slat made of wood or else of metal, which rods are as locks, or each fixed together at their hole in rank at that slat, in such a way that its end holds it so that none can move out and each of their tips is coiled so that each holds one of the rings and each of the rings has its tip inside.

And then at these closed tips the lock of the ring cannot move at the end, nor at the other side as the ring rests by the coiled tip inside the other ring. And these rings may be more than three as many as you please. But with less the game would not be as nice. And they are placed one to the other as can be seen in the 
figure [missing in the manuscript, cf. Figure 8 for our tentative reconstruction] except that the first of them does not have one inside.

Then, since we have made a loop, as you can see, closed at each end and such in a most beautiful way and skill are lined up all these rings starting from the first [0000000]. Thus the one which is free is placed in such a way: first, place this first one alone by passing it through the cut so that it can enter and all the others are remaining along that slat [0000001].

Next, take the second ring by pulling it up along the rod of the first and pulling it forward to the end of that loop. Leave it so that we have two already [0000011]. Then throw the first down to the slat to remain there [0000010]. And by the rod of the second you will pull up the third, pushing it forward so that the loop enters it, as you did before for the second [0000110]. When you have put up this third, next return to the first which you had thrown down, which is free by itself. And pull it up [0000111] and along the rod [of the first ring], you will throw down the second [0000101], and also that first [0000100], such that the only one remaining on the loop is the third [0000100].

Then, along the rod of this third you pull the fourth leading it to the end of the loop as you did before for the others [0001100]. Then reverse the order [of the moves] of the first two which you had thrown down and we have four on the loop [0001111]. Then, in the right order pull off the first, second and third, and only the fourth remains on the loop [0001000]. In the same way pull the fifth one up [0011000] and for the sixth it is necessary to return to all the first three in the same way, one by one [0011111]. And you will have six on the loop [0111111]. And to pull on the seventh it is first necessary to pull down the five first ones. Thus the first, second, third, fourth, fifth.

The fifth cannot be thrown when not having thrown the first, second, third [0111000]. Then, along the rod of the fourth one can throw down the fifth [0101000]. Then we return, the first, second, third [0101111], to drop down the fourth, which cannot be thrown if not along the rod of the third, which itself has to be placed up. And therefore we have to drop the first two. Thus, first, second [0101100], and by the rod of the said third we can throw down the fourth [0100100]. Then we throw down the third, but first we return to these two. Thus, the first, second [0100111] and we throw down the first [0100110]. Then, by the rod of the second the third is thrown down [0100010] as it climbed up. And so to shorten, you have all five off, and there only remains the sixth ring on the loop [0100000] by whose rod you can let go [up] the seventh [1100000]. And in this way, successively you can place the others, one after the other, and we spare the reader.

By which I not only described the method but actually demonstrated to exhaustion the youthful to learn. But I am very confident that your swift intelligence will fill the gaps of my terse writing in which many therefore rely on. And if of these [instruments] two are offered, one interlinked and the other loose, who first arranges one like the other wins. 


\section{Appendix 2: Cardano}

The transcription is based on the Opera Omnia and changes are tracked with the three previous editions of the Subtilitate: 1) Paris 1550, 2) Basel 1554 and 3) Basel 1560 (other editions are reprints of any of these). The changes are very minimal. The English translation is adapted from [10] as well as the French sixteenth century translation. As before, the states of the rings on the loop are shown with binary strings $s$ as explained in Section 4 put between square brackets: $[s]$.

\section{Liber XV, De incerti generis aut inutilibus subtilitatibus}

Verùm nullius vsus est instrumentum ex septem annulis. Bractea ferrea digitum lata, palmi longitudine, tenuis, in qua septem foramina, rotunda, angusta, æquísque spatiis, secundum longitudinem disposita, septem excipiunt virgulas tenues, altitudine vnciæ fermè, mobiles in imo, \& in suprema parte circumflexas, vt annulos digiti magnitudine inclusos retineant, ipse verò virgæ à sequenti annulo infra flexuram continentur. Ob idque omnes annuli præter primum, ab antecedente, ne exiliant liberè extra anteriorem virgam prohibentur: ferrea omnia \& ferrea etiam nauicula, cuius speciem ad vnguem in margine reddidimus, longa latáque pro magnitudine subiectæ laminæ. Hoc instrumento ludus excogitatus miræ subtilitatis. Primus, secundúsque annulus per inane A, spatium immittitur, inde nauicula per eosdem annulos, pòst illorum primus per inane $\mathrm{A}$, demittitur, post quem tertius annulus per nauiculæ vacuam mediam partem, vt primi duo sursum trahitur, illique nauicula intruditur: tum etiam primò sursum deducto, iam tres circumambiunt nauiculam ipsam: demittes igitur duos primos exempta prius nauicula, ita illa soli tertio inclusa manebit, inde quartum superinducere licebit, vt omnis hæc industria tribus præceptis contineatur. Primùm, quòd annulus sursum trahendus, dimittendúsve, vnum tantùm habeat ante se, cui nauicula includatur. Secundùm, vt dùm demittis, vnà semper primos duos demittat7, \& vnum trahat 8 , vel vnum demittendo duos primos trahat 9 . Tertiùm, vt quocunque sursum tracto, vel demisso, omnes qui antè sunt sursum trahere necesse est, ac rursus demittere. Primi itaque duo à nullo alio impediuntur, ne intercurrant: primum voco eum annulum, qui liber est. In sexagintaquatuor vicibus (si sine errore agatur) nauicula in omnibus includitur annulis, virgásque omnes inclusas continet in triginta vna, aliis vt nonaginta quinque ${ }^{10}$ sint ab absolutione ad primi transitum seu vltimi, redeat verò totidem. Igitur circulus perficietur totus in centum nonaginta vicibus. Inutile est hoc per se, sed tamen ad seras artificiosas arcarum transferri potest.

Book XV, On uncertain-type or useless subtleties

A tool made from seven rings is [a] real useless [subtlety]. A slat of iron a finger wide, a palm long, thin and with seven circular holes in it, delicately placed at equal distances along its length, of which come seven thin rods nearly an inch high, movable at the bottom, and at the top coiled around so that they hold

\footnotetext{
${ }^{7} 1550,1554,1560$ : demittas

${ }^{8} 1550,1554,1560$ : trahas

${ }^{9} 1550,1554,1560$ : trahas

${ }^{10} 1550$ : [aliis vt nonaginta quinque] alii in vltimam virgam navicula redigitur. Totidem verò vicibus redit, ita ut LXXXXV
} 


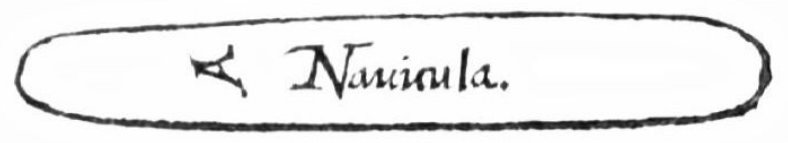

Figure 9: Cardano's illustration in the Subtilitate only shows the loop or shuttle (in 1550 without the word 'Nauicula')

enclosed rings a finger in size; the rods themselves are held beneath the coiled tip by the subsequent ring. Consequently, all the rings, apart from the first one, are restrained by the preceding ring from falling off by the rod in front. It is all of iron, and there is a small iron shuttle (which we presented with an accurate picture in the margin [cf. Figure 9]) that is long and wide according to the size of the underlying slat. With this tool a game of marvelous subtlety has been devised. The first and second ring are inserted through the empty space A and then the shuttle through these rings [0000011]. Afterwards, the first of these is passed through the empty space A [0000010], after which the third ring is taken up through the empty middle part of the shuttle, like the first two, and the shuttle is pushed into it [0000110]. Then when the first is pulled up, there are already three enclosing the shuttle [0000111]; you will pull out the first two that were freed from the shuttle first; so it rests enclosed by the third only [0000100]; next one may pull the fourth over [0001100], so that all this hard work is covered by three instructions. First, that the ring to be pulled up or dropped down should have only one in front of it enclosing the shuttle. Second, when you are dropping down, you should always let down the first two together after pulling up the first, or before dropping the first down you pull up the first two. Thirdly, whichever is pulled up or dropped, all those in front must be pulled up, and again be dropped. Thus the first two are not blocked by any other and neither do they interact [with each other]; the one I call the first ring is the one that is free[. ${ }^{11}$ In sixty-four exchanges, if no error is made, the shuttle is enclosed by all the rings, and encloses all the rods [1111111], after thirty-one others the shuttle is held only by the first rod [1000000]. So that there are ninety-five from the release [of the shuttle from the rings] to the transition of the first or the last, and equally many returning. So the circle will be completed in a hundred and ninety exchanges. This [subtlety] is of no use in itself, though it can be applied to the artful locks made for chests.

\footnotetext{
${ }^{11}$ This full stop is missing in the printed editions. This important omission drastically changes the interpretation of the text. Without the stop, the text is translated by [10 754] as "the first ring is the one that is free in sixty four exchanges". In our interpretation as two separate sentences, the text now makes sense within the mathematical context discussed above.
} 